\title{
Activation of Hydrogen Peroxide through Hydrogen-Bonding Interaction with Acidic Alcohols: Epoxidation of Alkenes in Phenol
}

Joos Wahlen, Dirk E. De Vos, and Pierre A. Jacobs*

Department of Interphase Chemistry, Centre for Surface Chemistry and Catalysis, Katholieke Universiteit Leuven, Kasteelpark Arenberg 23, B-3001 Heverlee, Belgium

pierre.jacobs@agr.kuleuven.ac.be

\section{SUPPORTING INFORMATION}

\section{Materials}

All materials were obtained from commercially available sources and were used without further purification. Hydrogen peroxide was a $50 \mathrm{wt}$ \% aqueous solution from Acros.

\section{Analysis, procedures and detailed results of control experiments}

\section{$\underline{\text { Hydrogen peroxide determination (Figure 1) }}$}

Hydrogen peroxide concentration was determined iodometrically. The composition of the reaction mixture was $5 \mathrm{mmol}$ cyclooctene, $50 \mathrm{mmol}$ phenol, and $5 \mathrm{mmol} \mathrm{H}_{2} \mathrm{O}_{2}(50 \mathrm{wt} \%)$. The reaction was stirred at $40{ }^{\circ} \mathrm{C}$. Typically, $200 \quad 1$ aliquots of the reaction mixture were quickly diluted into a solution of $20 \mathrm{~mL} \mathrm{H} \mathrm{H}_{2} \mathrm{O}, 2 \mathrm{~mL} 10$ wt.\% aqueous $\mathrm{KI}$, and $2.5 \mathrm{~mL}$ of a $5 \mathrm{M} \mathrm{H}_{2} \mathrm{SO}_{4}$ solution containing a catalytic amount of $\left(\mathrm{NH}_{4}\right)_{6} \mathrm{Mo}_{7} \mathrm{O}_{24} .4 \mathrm{H}_{2} \mathrm{O}$. The mixture was titrated with a $0.1 \mathrm{M}$ aqueous solution of $\mathrm{Na}_{2} \mathrm{~S}_{2} \mathrm{O}_{7}$ until the brown triiodide colour turned to a pale straw colour. Next, a few drops of a $10 \mathrm{~g} / \mathrm{L}$ aqueous starch solution were added and titration was continued until the colour of the solution changed from blue to colourless.

\section{$\underline{\text { GC and GC-MS analysis }}$}

For GC analysis, a Hewlett Packard 5890 gas chromatograph equipped with a $0.32 \mathrm{~mm}$ i.d. by $50 \mathrm{~m}$ WCOT fused silica column coated with a Chrompack CP-Sil 5 CB stationary phase (1.2 m $\left.\mathrm{d}_{\mathrm{f}}\right)$ was 
used. The instrument was equipped with a flame ionization detector (FID) and coupled to a HP 3396 integrator. Quantification of the reaction products was based on the internal standard technique $(n$ alkanes) using suitable response factors. Products were identified by comparison of their GC retention times with authentic epoxides prepared by $m$-CPBA oxidation in $\mathrm{CHCl}_{3}$ at $20{ }^{\circ} \mathrm{C}$. All compounds in Table 1 have been previously isolated and characterized. ${ }^{1}$ Additionally, GC-MS was used to confirm the identity of the products. A Fisons GC 8000 Series gas chromatograph equipped with a $0.32 \mathrm{~mm}$ i.d. by $60 \mathrm{~m}$ WCOT fused silica column coated with a Varian CP-Sil 5 CB Low bleed/MS stationary phase (0.25 $\left.\mathrm{m} \mathrm{d}_{\mathrm{f}}\right)$ was coupled to a Fisons MD 800 mass spectrometer.

$\underline{\text { General procedure for the phenol-promoted epoxidation of various alkenes (Table 1) }}$

A $20 \mathrm{~mL}$ flask was charged with $50 \mathrm{mmol}$ phenol, $5 \mathrm{mmol}$ alkene, $0.05 \mathrm{mmol} \mathrm{NaOAc}$, and $7.5 \mathrm{mmol}$ $\mathrm{H}_{2} \mathrm{O}_{2}$ (50 wt.\%). An appropriate alkane (n-octane, $n$-decane or $n$-tetradecane, $1 \mathrm{mmol}$ ) was added as an internal GC standard. The reaction mixture was stirred at the indicated temperature and the reaction was followed by GC analysis of the crude reaction mixture.

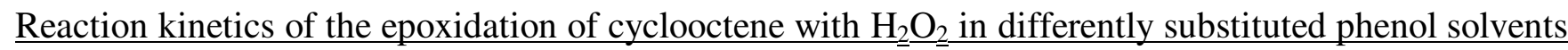
(Figure 2 and Figure 3 )

All kinetic experiments were carried out using cis-cyclooctene as the alkene substrate and $n$-decane as an internal GC standard. The reaction was followed by monitoring the disappearance of cyclooctene as a function of time. In all cases a complete selectivity to cyclooctene oxide was observed.

In a typical reaction, a $50 \mathrm{~mL}$ three-neck round-bottom flask was charged with $100 \mathrm{mmol}$ of the appropriate phenol, $10 \mathrm{mmol}$ cis-cyclooctene, $2 \mathrm{mmol} n$-decane (internal GC standard), $0.1 \mathrm{mmol}$ NaOAc, $15 \mathrm{mmol} \mathrm{H}_{2} \mathrm{O}_{2}$ (50 wt.\%), and $16 \mathrm{~mL}$ 1,2-dichloroethane. 1,2-Dichloroethane was used as a cosolvent to dissolve the high-melting phenols. The flask was immersed in an oil bath thermostated at 60 ${ }^{\circ} \mathrm{C}$ and the mixture was stirred magnetically. Samples were withdrawn periodically, quickly diluted in tetrahydrofuran, and analyzed by GC.

Second-order rate constants were calculated by plotting the following function $Y$ as a function of time:

$$
Y=(1 / s)\left\{\ln \left[\left(s+C_{\text {alkene }}\right) / C_{\text {alkene }}\right]-\ln \left[\left(s+C_{\text {alkene,initial }}\right) / C_{\text {alkene,initial }}\right]\right\}=k t \text {, with } s=C_{\mathrm{H} 2 \mathrm{O} 2}-C_{\text {alkene }}
$$

This equation is the solution of the differential equation $d C_{\text {alkene }} / d t=-k C_{\text {alkene }} C_{\mathrm{H} 2 \mathrm{O} 2}$ and is valid for $C_{\text {alkene,initial }} \neq C_{\mathrm{H} 2 \mathrm{O} 2 \text {,initial }}$. A plot of the concentration of cyclooctene versus time and the second-order plot 
for each phenol are shown in Figure S1 - S4. The corresponding second-order rate constants are summarized in Table S1 and Figure 2 (see manuscript).

Table S1. Rate constants for epoxidation of cyclooctene with $\mathrm{H}_{2} \mathrm{O}_{2}$ in differently substituted phenols.

\begin{tabular}{cc}
\hline substituted phenol & $k_{\mathrm{obs}}\left[\mathrm{M}^{-1} \cdot \mathrm{h}^{-1}\right]$ \\
\hline 2-chlorophenol & 0.035 \\
4-methoxyphenol & 0.044 \\
4-tert-butylphenol & 0.079 \\
phenol & 0.082 \\
4-methylphenol & 0.083 \\
4-chlorophenol & 0.224 \\
4-nitrophenol & 0.330 \\
3-nitrophenol & 0.339 \\
3-chlorophenol & 0.365 \\
\hline
\end{tabular}

Under the same reaction conditions, but in the absence of phenol, a conversion of only $2 \%$ was obtained after $23 \mathrm{~h}$.
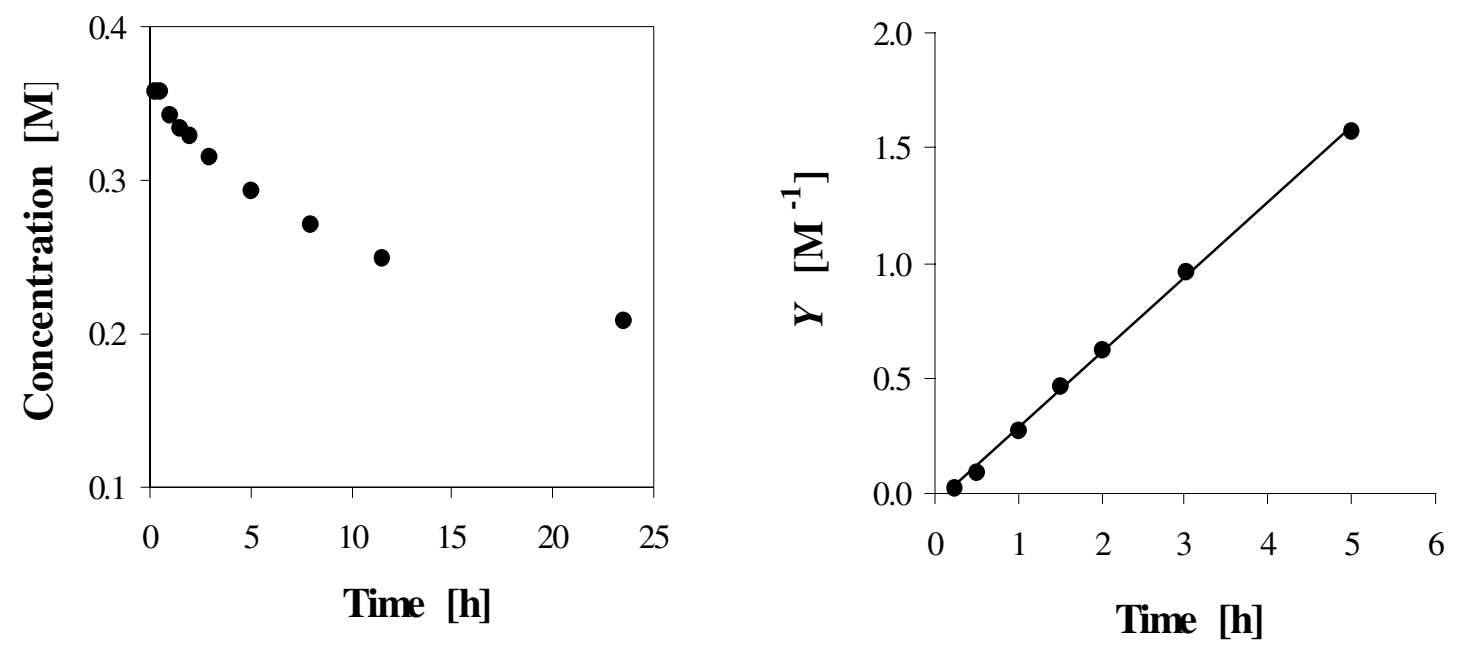

Figure S1. Epoxidation of cyclooctene with $\mathrm{H}_{2} \mathrm{O}_{2}$ in phenol.

Reaction conditions: $10 \mathrm{mmol}$ cyclooctene, $2 \mathrm{mmol}$-decane, $0.1 \mathrm{mmol} \mathrm{NaOAc}, 15 \mathrm{mmol}_{2} \mathrm{O}_{2}, 100$ mmol phenol, $16 \mathrm{~mL}$ 1,2-dichloroethane, $60{ }^{\circ} \mathrm{C}$. 

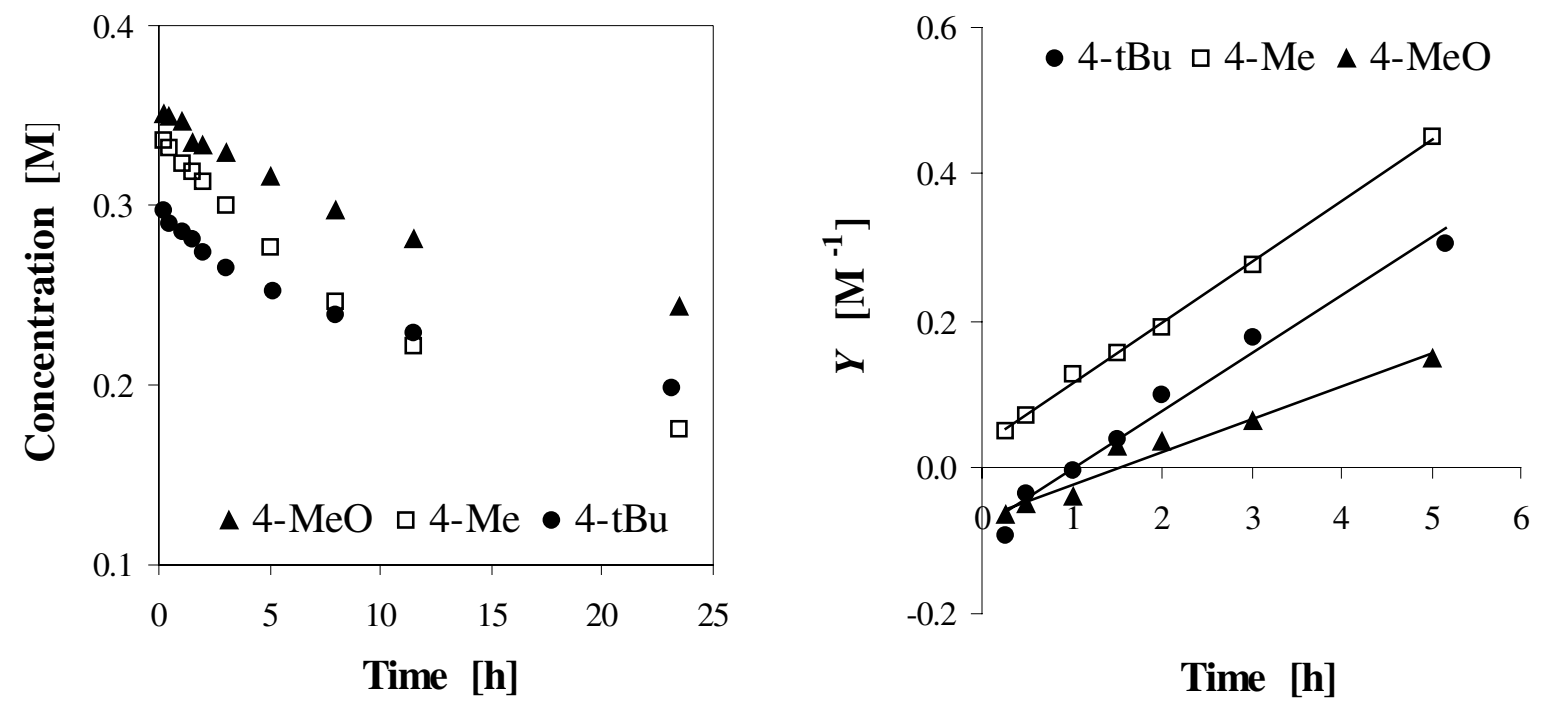

Figure S2. Epoxidation of cyclooctene with $\mathrm{H}_{2} \mathrm{O}_{2}$ in 4-methyl-, 4-tert-butyl-, and 4-methoxyphenol. Reaction conditions: $10 \mathrm{mmol}$ cyclooctene, $2 \mathrm{mmol} \mathrm{n-decane,} 0.1 \mathrm{mmol} \mathrm{NaOAc}, 15 \mathrm{mmol} \mathrm{H}_{2} \mathrm{O}_{2}, 100$ mmol p-substituted phenol, $16 \mathrm{~mL}$ 1,2-dichloroethane, $60^{\circ} \mathrm{C}$.
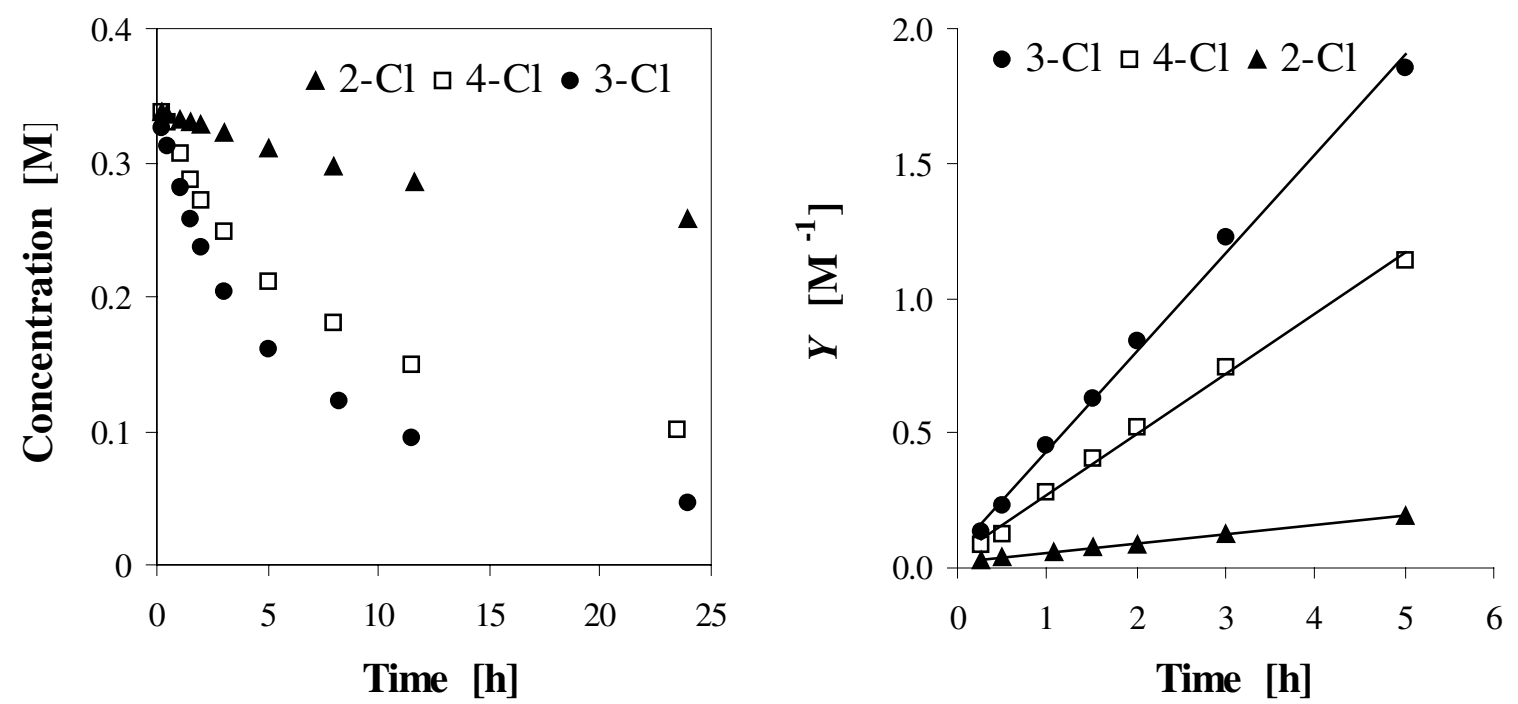

Figure S3. Epoxidation of cyclooctene with $\mathrm{H}_{2} \mathrm{O}_{2}$ in 2-, 3-, and 4-chlorophenol.

Reaction conditions: 10 mmol cyclooctene, 2 mmol n-decane, 0.1 mmol $\mathrm{NaOAc}, 15 \mathrm{mmol} \mathrm{H}_{2} \mathrm{O}_{2}, 100$ mmol chlorophenol, $16 \mathrm{~mL}$ 1,2-dichloroethane, $60{ }^{\circ} \mathrm{C}$. 

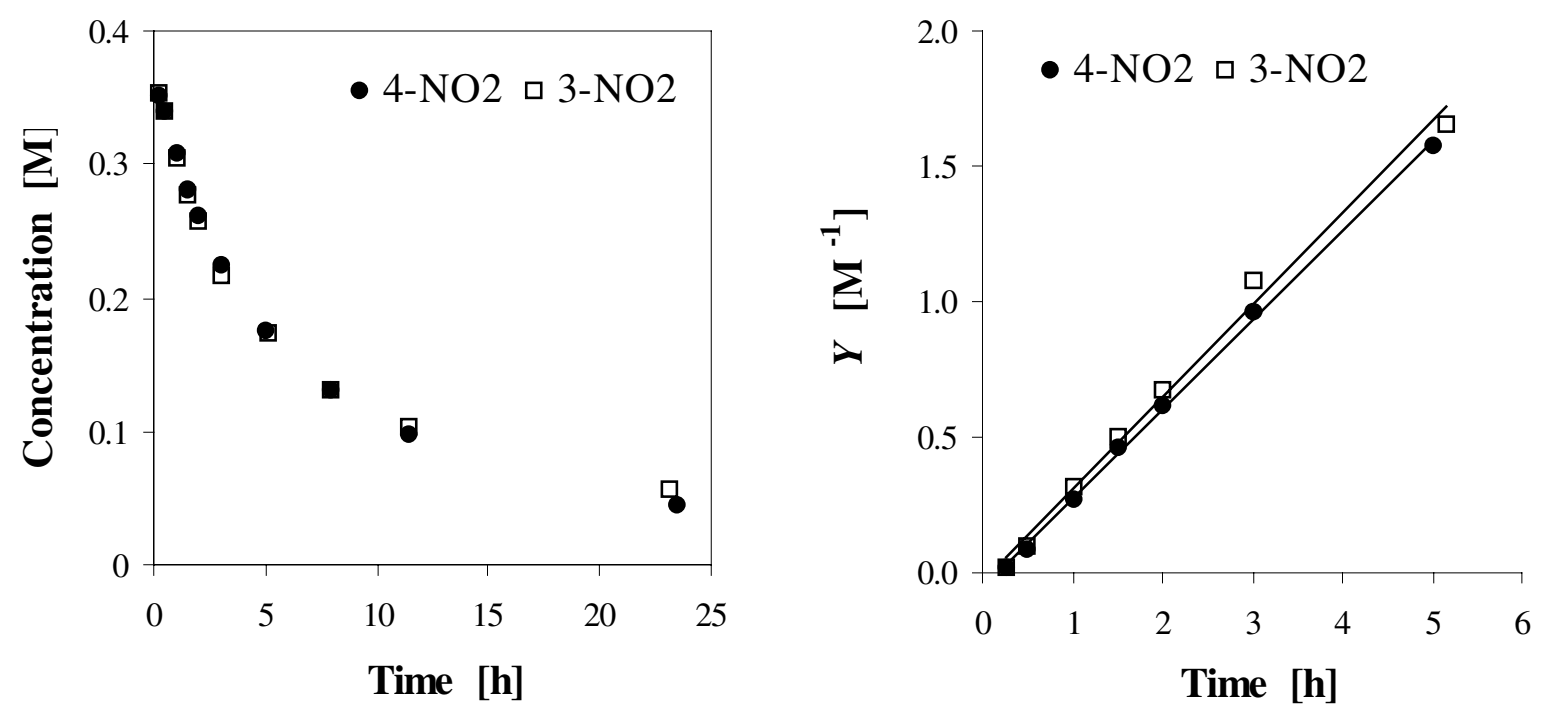

Figure S4. Epoxidation of cyclooctene with $\mathrm{H}_{2} \mathrm{O}_{2}$ in 3- and 4-nitrophenol.

Reaction conditions: $10 \mathrm{mmol}$ cyclooctene, $2 \mathrm{mmol}$-decane, $0.1 \mathrm{mmol} \mathrm{NaOAc}, 15 \mathrm{mmol}_{2} \mathrm{O}_{2}, 100$ mmol nitrophenol, $16 \mathrm{~mL} \mathrm{1,2-dichloroethane,} 60{ }^{\circ} \mathrm{C}$.

$\underline{\text { Control experiment 1. Epoxidation of cyclooctene in various alcohol solvents }}$

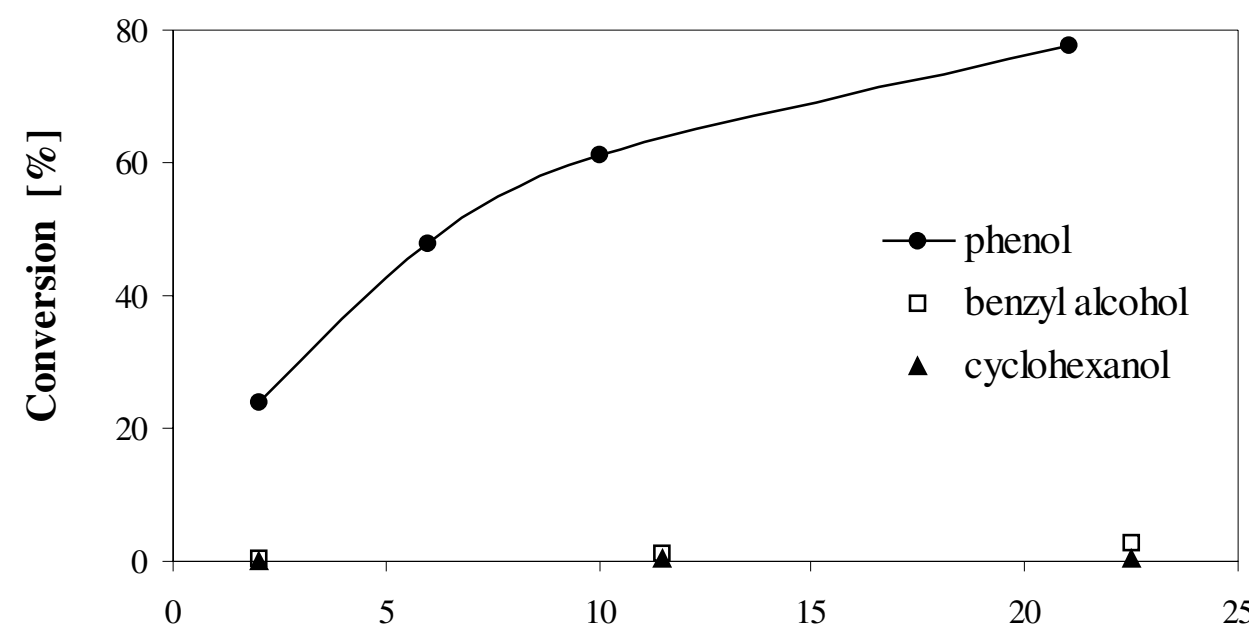

Time [h]

Figure S5. Epoxidation of cyclooctene with $\mathrm{H}_{2} \mathrm{O}_{2}$ in phenol, benzyl alcohol, and cyclohexanol.

Reaction conditions: 5 mmol cyclooctene, 1 mmol n-decane, 0.05 mmol $\mathrm{NaOAc}$, $7.5 \mathrm{mmol}_{2} \mathrm{O}_{2}$, 50 mmol solvent, $40^{\circ} \mathrm{C}$.

Under the same reaction conditions, but using anisole (methoxybenzene) as a solvent, conversion was lower than $1 \%$ after $24 \mathrm{~h}$. 
Control experiment 2. Effect of the addition of a metal-complexing agent on the epoxidation of cyclooctene

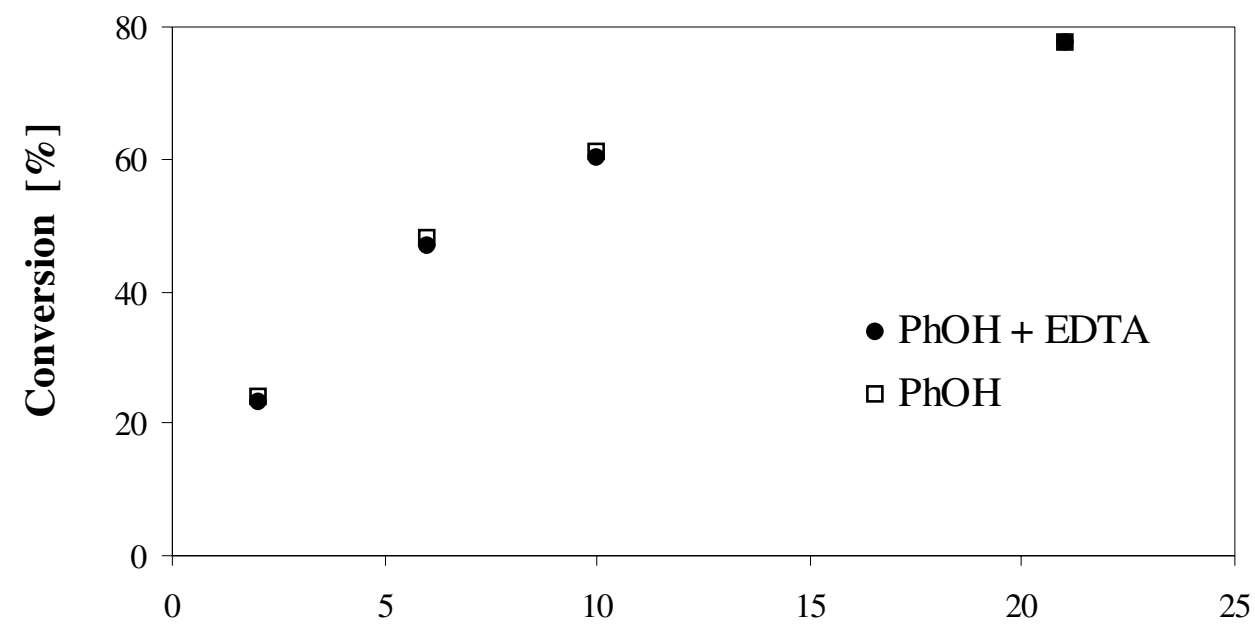

Time [h]

Figure S6. Epoxidation of cyclooctene with $\mathrm{H}_{2} \mathrm{O}_{2}$ in phenol in the presence or absence of EDTA.

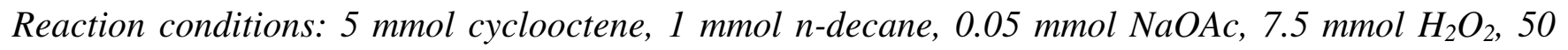
mmol phenol, $40{ }^{\circ} \mathrm{C}$, 0 or 0.25 mmol EDTA.

Control experiment 3. Effect of the addition of a radical scavenger on the epoxidation of cyclooctene

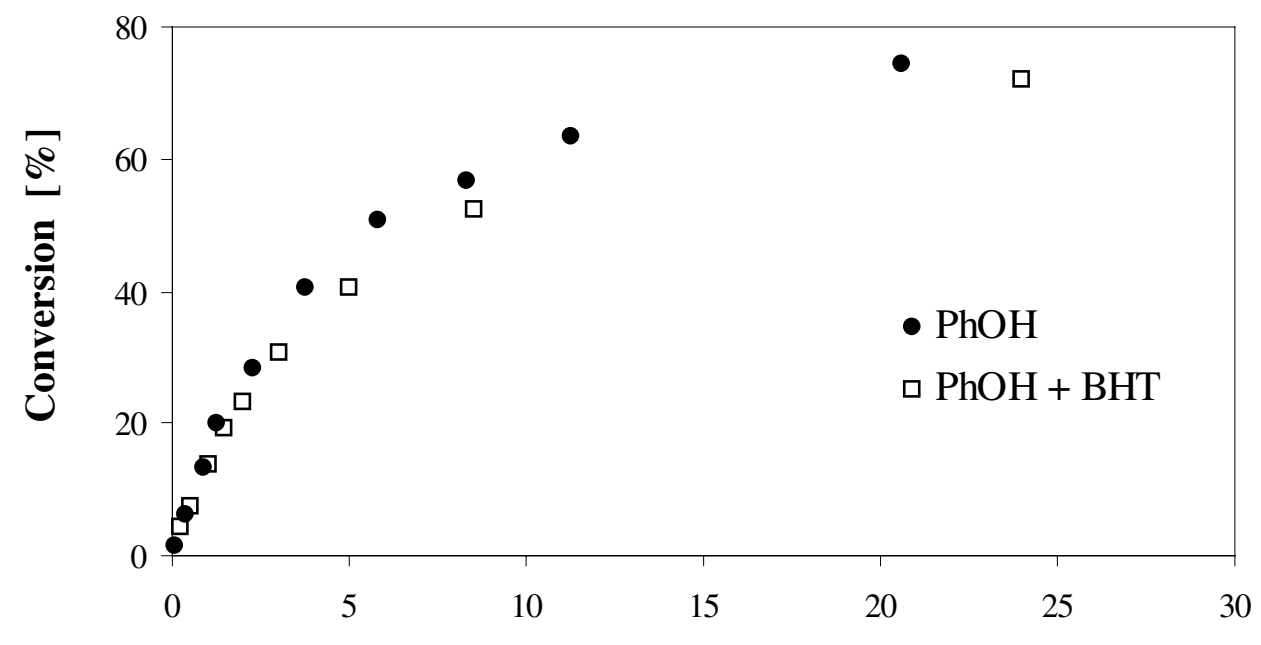

Time [h]

Figure S7. Epoxidation of cyclooctene with $\mathrm{H}_{2} \mathrm{O}_{2}$ in phenol $(\mathrm{PhOH})$ in the presence or absence of 2,6di-tert-butyl-p-cresol (BHT).

Reaction conditions: $10 \mathrm{mmol}$ cyclooctene, $2 \mathrm{mmol}$ n-decane, $0.1 \mathrm{mmol} \mathrm{NaOAc}, 10 \mathrm{mmol}_{2} \mathrm{O}_{2}, 100$ mmol phenol, $40^{\circ} \mathrm{C}, 0$ or $0.5 \mathrm{mmol} \mathrm{BHT}$. 

$\underline{\text { with } \mathrm{H}_{2}} \underline{\mathrm{O}}_{2} \underline{\text { in phenol }}$

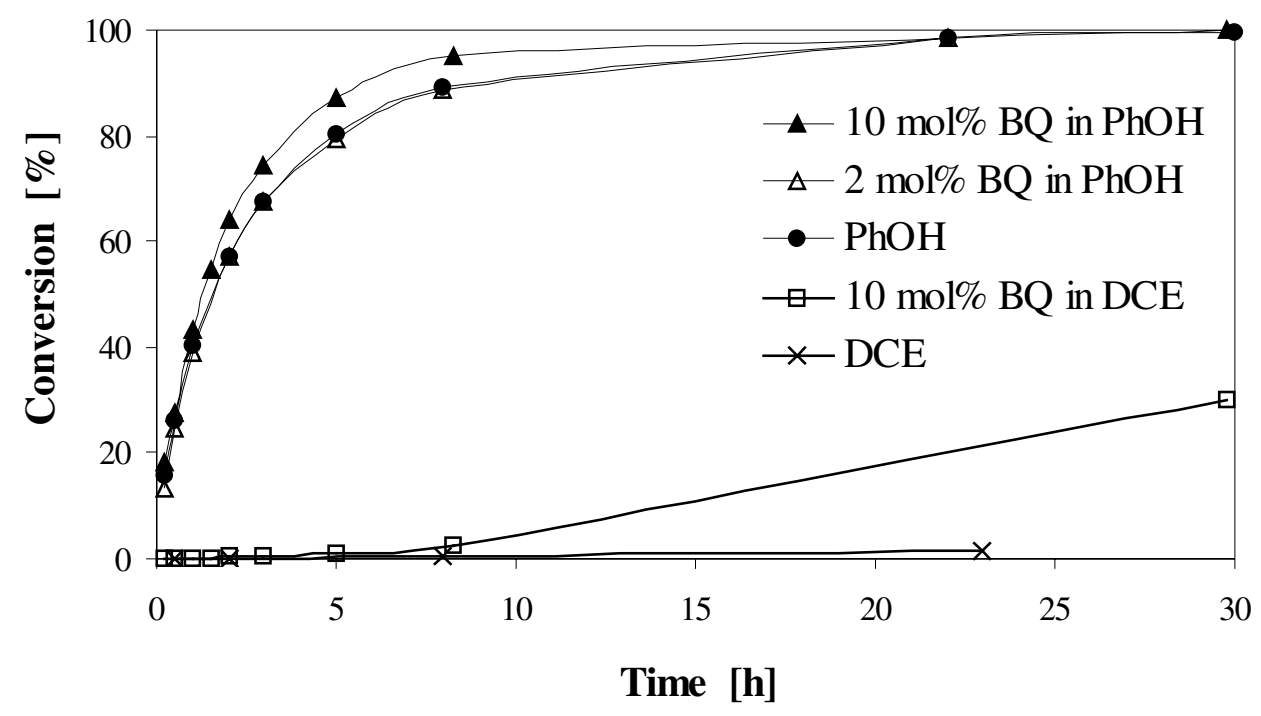

Figure S8. Epoxidation of cyclooctene with $\mathrm{H}_{2} \mathrm{O}_{2}$ in phenol $(\mathrm{PhOH})$ or 1,2-dichloroethane (DCE) in the presence or absence of benzoquinone (BQ). Mol\% is relative to cyclooctene.

Reaction conditions: 5 mmol cyclooctene, 1 mmol n-decane, 0.05 mmol NaOAc, $7.5 \mathrm{mmol} \mathrm{H}_{2} \mathrm{O}_{2}, 50$ mmol phenol or $8 \mathrm{~mL} \mathrm{1,2-dichloroethane,} 60^{\circ} \mathrm{C}, 0 \mathrm{mmol}, 0.1 \mathrm{mmol}$, or $0.5 \mathrm{mmol}$ benzoquinone.

The added BQ (2 and $10 \mathrm{~mol} \%$ ) was detectable by GC analysis. The amount of BQ remained on an almost constant level, and slightly increased towards the end of the reaction.

Under the same reaction conditions, the epoxidation of cyclooctene with $\mathrm{H}_{2} \mathrm{O}_{2}$ in 1,2-dichloroethane (8 $\mathrm{mL}$ ) instead of phenol in the presence of 1, 10, 100, and $1000 \mathrm{~mol} \%$ benzoquinone relative to cyclooctene gave $3,14,20$, and $22 \%$ conversion after $22 \mathrm{~h}$. In methanol (10 mL) instead of phenol in the presence of $10 \mathrm{~mol} \% \mathrm{BQ}$ relative to cyclooctene $2 \%$ conversion was obtained after $22 \mathrm{~h}$.

Note that in none of our reactions with pure phenol, benzoquinone was formed in a concentration larger than $1 \mathrm{~mol} \%$ with respect to starting alkene. This demonstrates that BQ is a much less strong promotor of epoxidation than phenol itself; the fast epoxidation of cyclooctene in phenol cannot be due to the formation of a phenol oxidation product such as BQ. 
Control experiment 5. Effect of the addition of catechol or hydroquinone on the epoxidation of cyclooctene with $\mathrm{H}_{2} \underline{\mathrm{O}}_{2} \underline{\text { in phenol }}$

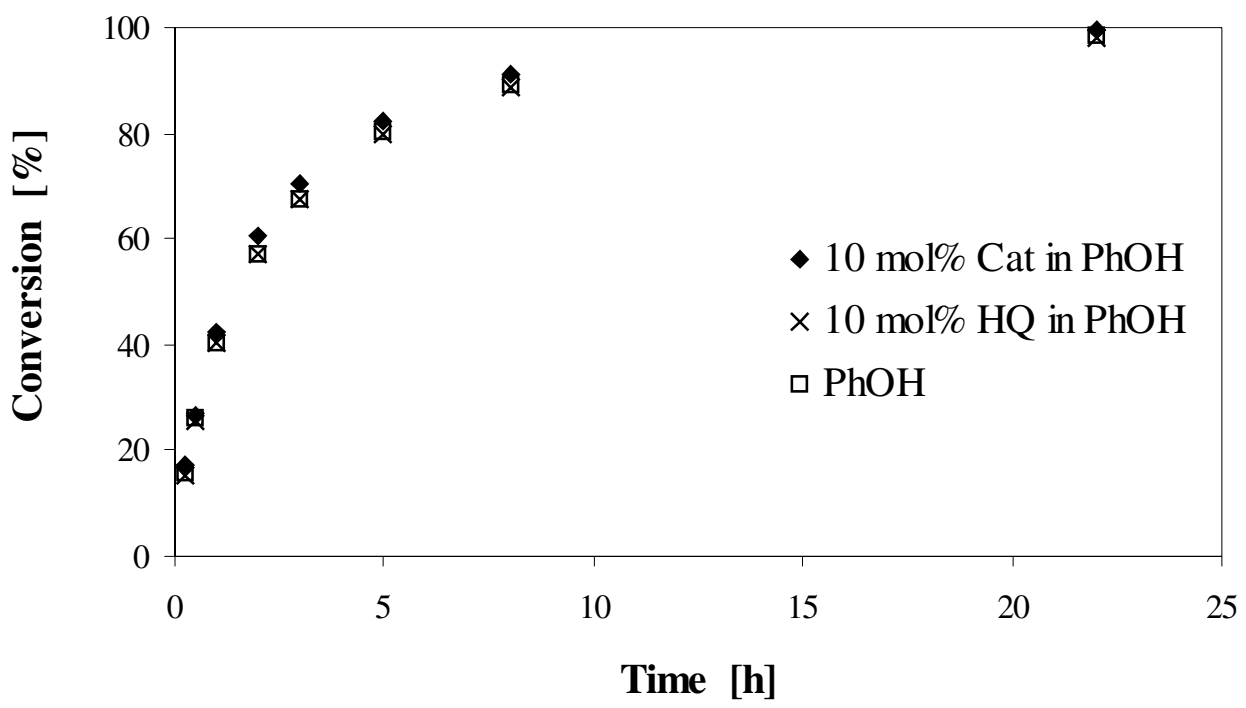

Figure S9. Epoxidation of cyclooctene with $\mathrm{H}_{2} \mathrm{O}_{2}$ in phenol $(\mathrm{PhOH})$ in the presence of catechol $(\mathrm{Cat})$ or hydroquinone (HQ). Mol\% is relative to cyclooctene.

Reaction conditions: 5 mmol cyclooctene, 1 mmol n-decane, 0.05 mmol $\mathrm{NaOAc}, 7.5 \mathrm{mmol}_{2} \mathrm{O}_{2}, 50$ mmol phenol, $60^{\circ} \mathrm{C}, 0 \mathrm{mmol}$ or $0.5 \mathrm{mmol}$ catechol or hydroquinone.

Under the same reaction conditions, the epoxidation of cyclooctene with $\mathrm{H}_{2} \mathrm{O}_{2}$ in 1,2-dichloroethane (8 $\mathrm{mL}$ ) instead of phenol in the presence of $10 \mathrm{~mol} \%$ catechol or $10 \mathrm{~mol} \%$ hydroquinone relative to cyclooctene gave $3 \%$ and $3 \%$ conversion after $22 \mathrm{~h}$.

Epoxidation of cyclooctene with tert-butyl hydroperoxide (TBHP) in phenol

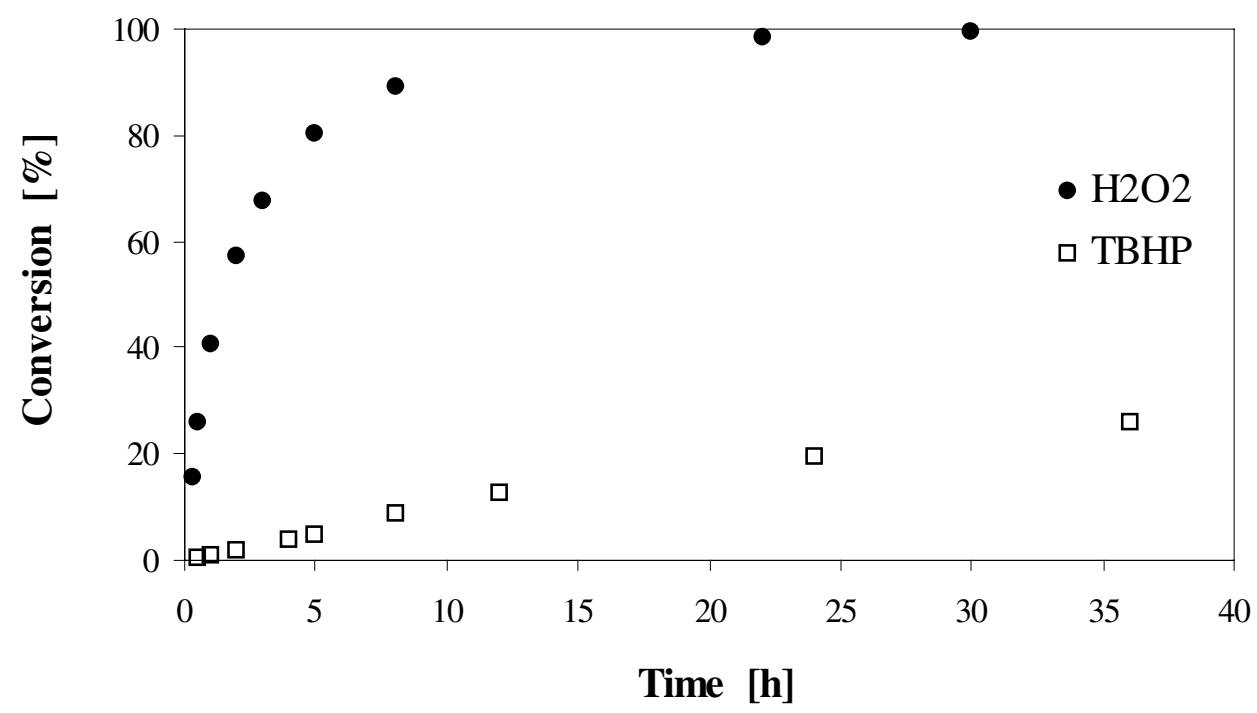

Figure S10. Epoxidation of cyclooctene with hydrogen peroxide or tert-butyl hydroperoxide in phenol.

Reaction conditions: 5 mmol cyclooctene, 1 mmol n-nonane, 0.05 mmol NaOAc, $7.5 \mathrm{mmol} \mathrm{H}_{2} \mathrm{O}_{2}(50$ wt.\%) or $7.5 \mathrm{mmol} \mathrm{TBHP}\left(5.5 \mathrm{M}\right.$ in n-decane), $50 \mathrm{mmol}$ phenol, $60^{\circ} \mathrm{C}$. 
Influence of the water content of $\mathrm{H}_{2} \underline{\mathrm{O}}_{2}$ and the addition of epoxide product on the epoxidation of cyclooctene with $\mathrm{H}_{2} \underline{\mathrm{O}}_{2}$ in phenol

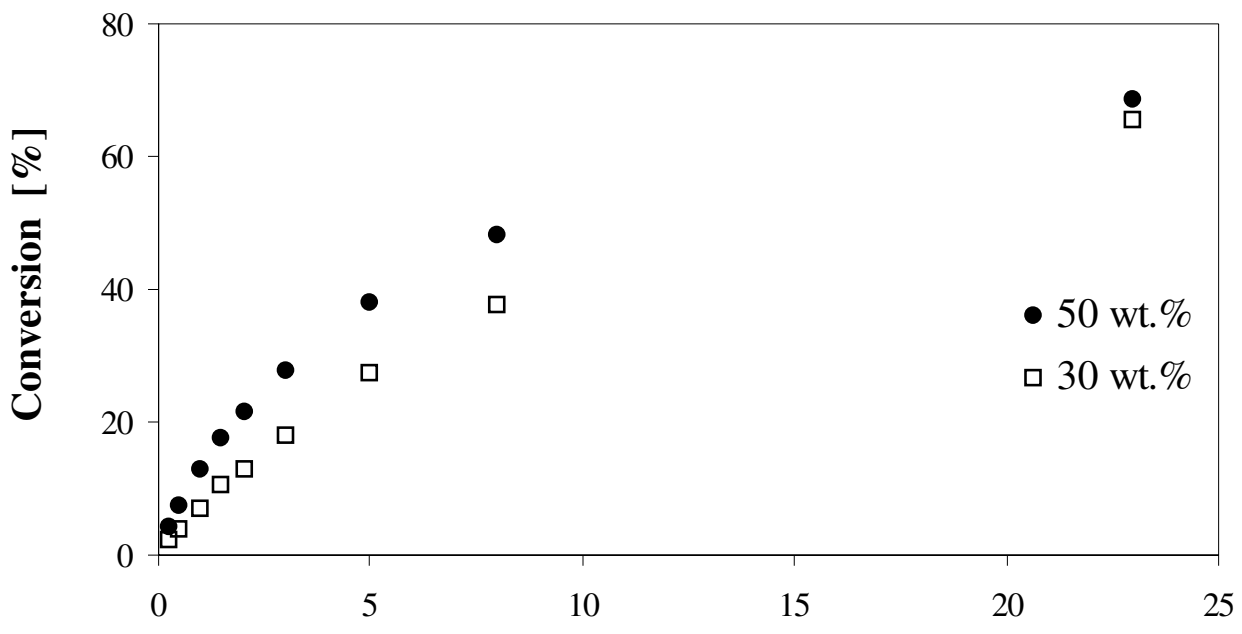

Time [h]

Figure S11. Epoxidation of cyclooctene with 30 wt. $\%$ or 50 wt. $\% \mathrm{H}_{2} \mathrm{O}_{2}$ in phenol.

Reaction conditions: 5 mmol cyclooctene, 1 mmol n-decane (internal standard), 0.05 mmol NaOAc, 5 mmol $\mathrm{H}_{2} \mathrm{O}_{2}$ (30 or 50 wt.\%), 50 mmol phenol, $40{ }^{\circ} \mathrm{C}$.

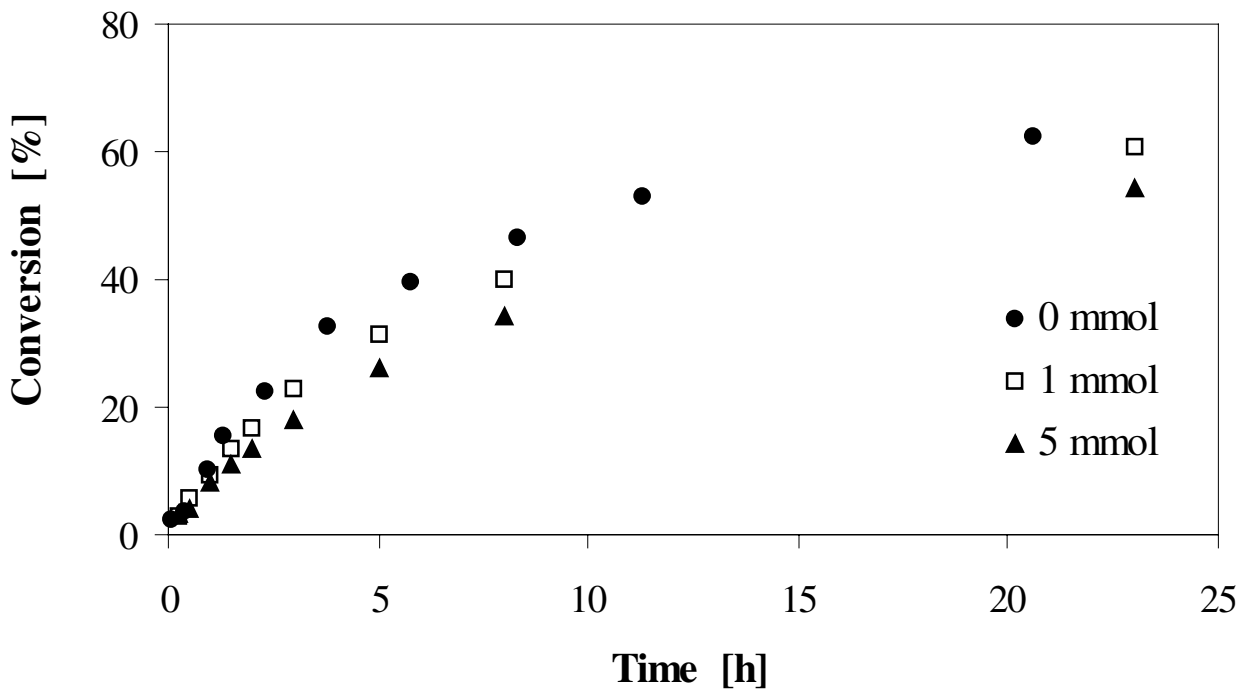

Figure S12. Effect of cyclooctene oxide addition on cyclooctene epoxidation with $\mathrm{H}_{2} \mathrm{O}_{2}$ in phenol.

Reaction conditions: $10 \mathrm{mmol}$ cyclooctene, $2 \mathrm{mmol}$-decane, $0.1 \mathrm{mmol} \mathrm{NaOAc}, 10 \mathrm{mmol} \mathrm{H}_{2} \mathrm{O}_{2}, 100$ mmol phenol, $40{ }^{\circ} \mathrm{C}$, x mmol cyclooctene oxide added at the start of the reaction (see legend). 


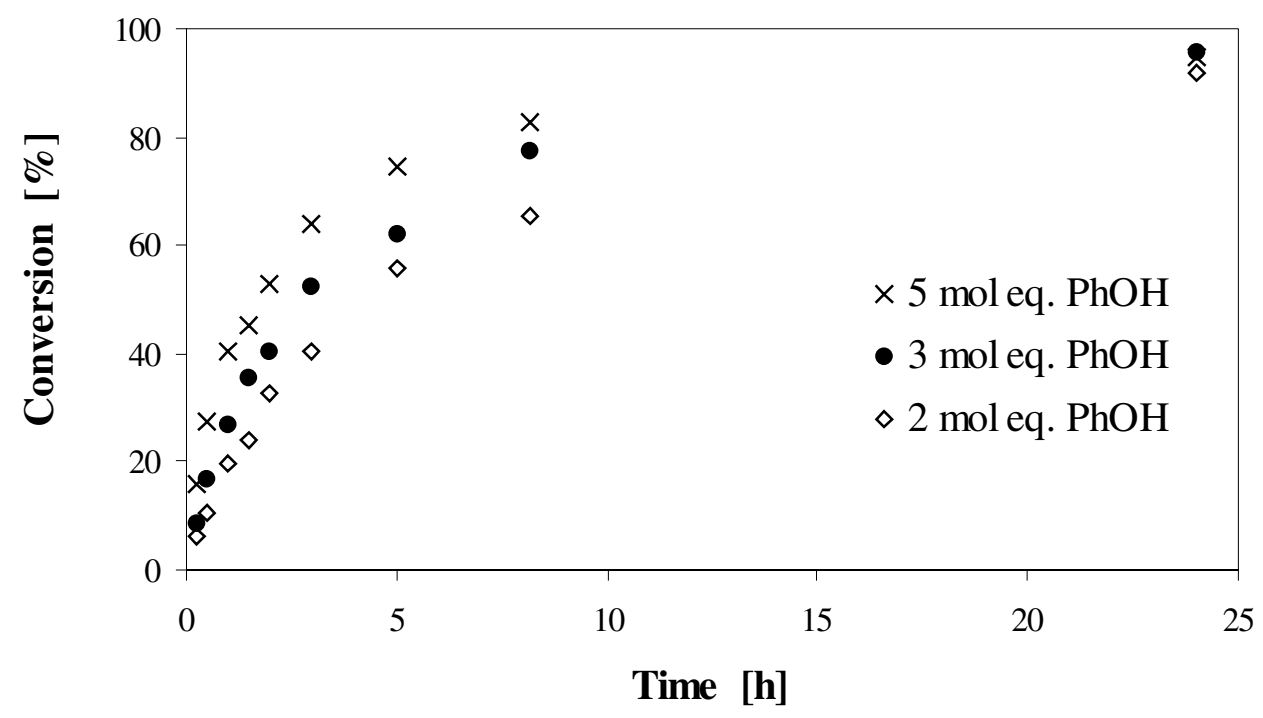

Figure S13. Epoxidation of cyclooctene with $\mathrm{H}_{2} \mathrm{O}_{2}$ in 2, 3, and 5 mol equivalents of phenol. Reaction conditions: 5 mmol cyclooctene, 1 mmol n-decane, 0.05 mmol NaOAc, $5 \mathrm{mmol} \mathrm{H}_{2} \mathrm{O}_{2}, 10,15$, or 25 mmol phenol, $60^{\circ} \mathrm{C}$.

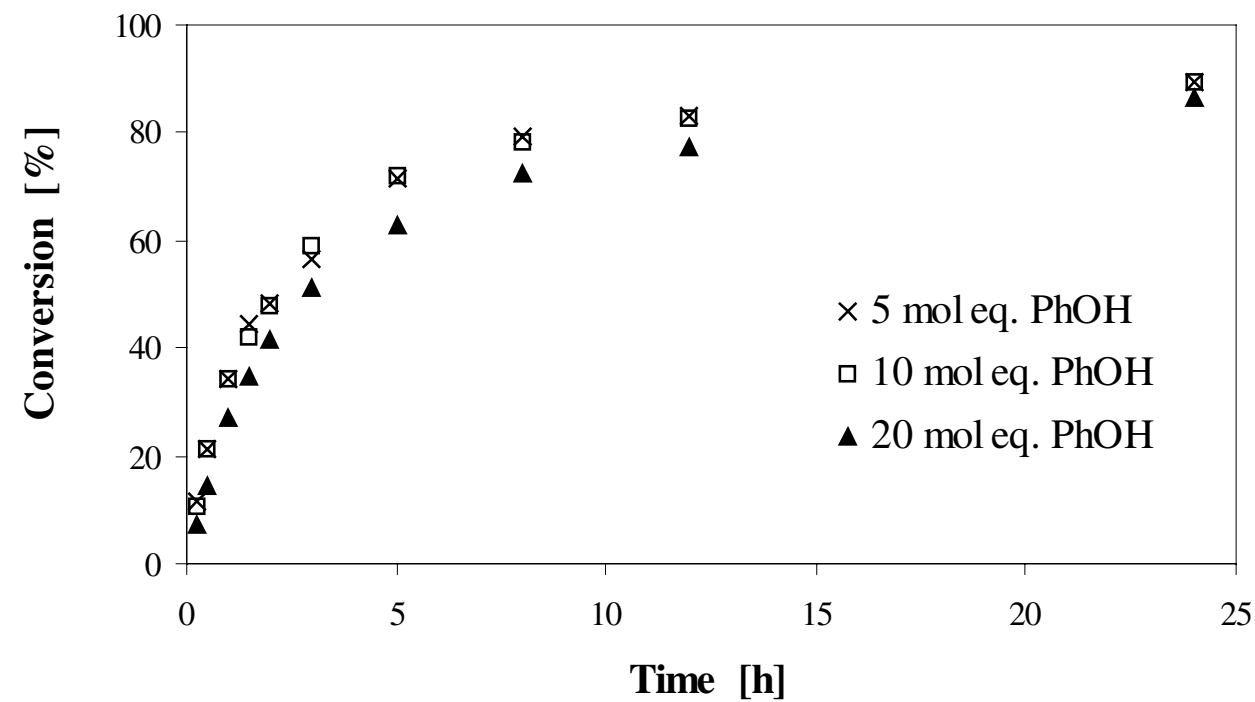

Figure S14. Epoxidation of cyclooctene with $\mathrm{H}_{2} \mathrm{O}_{2}$ in 5, 10, and 20 mol equivalents of phenol.

Reaction conditions: 5 mmol cyclooctene, $1 \mathrm{mmol}$-decane, 0.05 mmol NaOAc, $5 \mathrm{mmol} \mathrm{H}_{2} \mathrm{O}_{2}, 25$, 50, or $100 \mathrm{mmol}$ phenol, $60^{\circ} \mathrm{C}$.

\section{References}

(1) Villa de P., A. L.; Sels, B. F.; De Vos, D. E.; Jacobs, P. A. J. Org. Chem. 1999, 64, 7267-7270 and references cited therein. 